$\mathbb{T}$ periodica polytechnica

\author{
Civil Engineering \\ 58/2 (2014) 105 -112 \\ doi: $10.3311 /$ PPci.7485 \\ http://periodicapolytechnica.org/ci \\ Creative Commons Attribution (1) \\ RESEARCH ARTICLE
}

\section{Integral water management}

Flora Ijjas

Received 2011-11-01, revised 2012-03-02, accepted 2012-07-02

\begin{abstract}
Population growth, growing food and energy demand, changing climate, water shortages - great challenges for society. Water resources management also needs to become more resilient in order to adapt. This article offers a new way of looking at water related problems. The special approach of integral water management (not to be mistaken for integrated water management) shows hidden linkages behind water related processes. Water problems are human problems and are not to be solved without understanding the human factor behind. This way cause and effect becomes clearer and the wider understanding offers a higher opportunity to find the right solutions.
\end{abstract}

\section{Keywords}

integral water management $\cdot$ value driven measures - integrated technical and philosophical aspects

\section{Flora ljjas}

MSc, lecturer assistant, Budapest University of Technology and Economics, Department of Environmental Economics, Magyar tudósok krt. 2., H-1117, Budapest, Hungary

e-mail: fijjas@eik.bme.hu

\section{Introduction}

1.1 What the word integral means in water management

For industrialized and urbanized river basins the achievement of good qualitative and quantitative status of all water bodies by 2015 - as main goal of the Directive 2000/60/EC of the European Parliament and of the Council of 23 October 2000 - depends on many factors. Such as the future landscaping measures that are necessitated by climate change [2] or any other influences. However as landscaping measures are human induced actions, good water status depends on human choices.

Water management should fulfill the needs of society. These needs differ between one social value system to another and the choices made for landscaping measures also depend on these needs. Value systems shall therefore be handled as main indicators for water management. More focus is to be added on what these human needs are, how they change in time, and what they are based on. Drivers as traditions, education and other human factors shall be mapped and defined. Integral water management offers a methodology for that purpose.

Integral water management analyzes the human factor of water related problems and applies integrated water management techniques.

\subsection{Integral vs. integrated water management}

In 2002 the Technical Advisory Committee of the Global Water Partnership defined integrated water resources management at the Johannesburg World Summit on Sustainable Development "as a process, which promotes the coordinated development and management of water, land and related resources in order to maximize the resultant economic and social welfare in an equitable manner without compromising the sustainability of vital ecosystems," and said that water should be managed under the principles of good governance, public participation, and in a basin-wide context.

In order to maximize social welfare and to successfully use the principle of public participation, the needs and values of society must be understood. Although integrated water management highlights the importance of these interior aspects, it doesn't try to map, analyze and respond to those. Integral water 
management aims to fill this gap: the needs of society that are to be fulfilled are being mapped in four quadrants using Integral theory by Ken Wilber [3] [6]:

The four quadrants cover four different groups of needs at three levels (physiosphere, biosphere, noosphere):

- Upper right (UR): Individual, objective needs (e.g. at level of biosphere: high life-expectancy)

- Upper left (UL): Individual, subjective needs (e.g. at level of noosphere: high life-satisfaction and well-being)

- Lower left (LL): Collective subjective needs (e.g. at level of noosphere: acceptance of different value systems, peace)

- Lower right (LR): Collective, objective needs (e.g. at level of noosphere: Social equity (uniform distribution); Economic efficiency (Pareto efficiency); and Ecological sustainability)

Integrated water management only focuses on two of the quadrants:

- (UR) Individual, objective needs - good physical, chemical, biological status of river systems (e.g. good water quality)

- (LR) Collective, objective needs - economic (e.g. sustainable water management) social and legal (e.g. WFD stakeholder involvement) sustainability

Whereas Integral water management further includes the other two quadrants that focus on the human aspect that are mapped by the subjective quadrants:

- (UL) Individual, subjective needs - psychological aspects (e.g. subjective well-being)

- (LL) Collective subjective needs - ethical aspects (e.g. peaceful cooperation between different cultures of upstream and downstream countries)

According to Figure 1 - integral water management can be defined as a concept that works with the physical, chemical, biological, ecological, but also the economic, social, legal, and cultural aspects of water systems. These relate to different human values and needs such as access to safe water, water justice, well-being; etc.

\subsection{Value systems and integral water management}

Human needs that strongly form water management can be grouped to different value systems. The psychosocial developmental model by Clare W. Graves [5] [9] is a widely used and practical classification model of emerging value systems. Graves identified eight major value systems that can be described by life conditions and the brain's coping conditions with them. The eight levels of existence are: A-N Automatic; BO Autistic, C-P Egocentric, D-Q Absolutistic, E-R Multiplistic, F-S Relativistic, G-T Systemic, and the H-U Differential level. 'A' stands for the neurological system in the brain upon which the psychological system is based. ' $N$ ' stands for the existential problems that can be coped with the 'A' neurological system. The different states arise and come to stage center in man's mind as each successive set of human problems are resolved. Using Graves' model we have formed a developmental model of human needs and ethical values in social systems which is useable to simulate optional adaptation strategies to water challenges [4]:

In the next chapter the application of emerging value systems model in scenario methodology will be presented. It shows how the shifts in value systems provide a guide for selecting and positioning specific landscaping measures.

\section{Integral water management practice in Europe}

2.1 Value-driven scenarios on the geomorphology and ecology of lower Rhine floodplains

Within the cooperation of the Utrecht University and another research institution [10] the great potential for the application of psychosocial developmental models in river management is illustrated. The study presents a new methodology of developing and evaluating scenarios for river management strategies by integrating psychology and sociology with ecology and geomorphology.

Translation of the psychosocial model-based scenarios into specific spatial layouts of landscaping measures was done [10] by a workshop that brought ten experts together with backgrounds in ecology, hydraulics, cyclic floodplain rejuvenation, transition management, integrated river management and geomorphology. The workshop participants were given a presentation to clarify the mindset of people living according to different value systems (Table 1). Subsequently, the participants agreed upon landscaping measures (Table 2 ) representative for three respective value systems out of Graves' eight major value systems.

They stated that the current dominant value system in the Netherlands, with its consensual attitude and attention for ecology and landscape diversity, can be considered Systemic (F-S) [10]. Hence, a Systemic value system provided the logical starting point for the scenarios. Starting from there, they have proposed three different scenarios that are likely given the possible dynamics in value systems in relation to the time horizon of 2050. The scenarios are the following:

1 F-S: strengthening of the Relativistic value system

2 E-R: shifting to lower level Multiplistic value system

3 G-T: shifting to higher level Systemic value system

The Multiplistic value system was oriented towards low costs, blue print, being engineering-dominated, water follows function, and low hydrodynamic roughness. The Relativistic value system was translated into landscaping measures that could be the result of consensus finding, equality between different groups, 'grass roots', and natural design. The landscaping measures for the Systemic scenario had to display adaptation of incorporating novel techniques, a big picture view, natural design, 
Tab. 1. Emerging value systems and needs

\begin{tabular}{|c|c|c|c|}
\hline Für-ljjas levels & Main needs & Life conditions & Coping tools \\
\hline Surviving individuals & biophysical needs & $\begin{array}{c}\mathrm{N} \text { - State of nature, } \\
\text { biological urges and } \\
\text { drives: physical senses } \\
\text { dictate the state of being }\end{array}$ & $\begin{array}{l}\text { A - Instinctive: natural } \\
\text { instincts and reflexes } \\
\text { direct; automatic } \\
\text { existence }\end{array}$ \\
\hline Superstitious clans/tribes & $\begin{array}{l}\text { temporary security within } \\
\text { group }\end{array}$ & $\begin{array}{l}\text { O - Threatening and full } \\
\text { of mysterious powers } \\
\text { and spirits that must be } \\
\text { placated and appeased }\end{array}$ & $\begin{array}{l}\text { B - Animistic: according } \\
\text { to tradition and ritual } \\
\text { ways of the group/tribe }\end{array}$ \\
\hline Egocentric warriors & individual security & $\begin{array}{l}\mathrm{P} \text { - The world is a jungle } \\
\text { where the strong prevail } \\
\text { and the weak serve. } \\
\text { Nature is to be } \\
\text { conquered. }\end{array}$ & $\begin{array}{l}\mathrm{C} \text { - Egocentric: ego } \\
\text { wants dominance, } \\
\text { conquest and power; } \\
\text { exploitive, aggressive }\end{array}$ \\
\hline Conformist groups & $\begin{array}{l}\text { long term safety within } \\
\text { group }\end{array}$ & $\begin{array}{l}\text { Q - Higher authority } \\
\text { punishes bad behavior } \\
\text { but rewards good work. }\end{array}$ & $\begin{array}{l}\text { D- Absolutistic: obedient, } \\
\text { conforming; } \\
\text { conservative, hierarchic, } \\
\text { driven by guilt }\end{array}$ \\
\hline Creative hedonists & $\begin{array}{c}\text { long term individual } \\
\text { safety, mental, } \\
\text { behavioral independence }\end{array}$ & $\begin{array}{l}\mathrm{R} \text { - The environment is } \\
\text { full of resources; the } \\
\text { world is full of } \\
\text { possibilities. }\end{array}$ & $\begin{array}{l}\text { E - Multiplistic: } \\
\text { pragmatic to achieve } \\
\text { results; testing options, } \\
\text { rational, modern, } \\
\text { effective, selfish, } \\
\text { arrogant, creative }\end{array}$ \\
\hline $\begin{array}{c}\text { Communities of human } \\
\text { beings }\end{array}$ & $\begin{array}{l}\text { long term individual } \\
\text { safety within group, } \\
\text { emotional freedom }\end{array}$ & $\begin{array}{l}\text { S - Humanity is living in a } \\
\text { habitat wherein people } \\
\text { can find love and } \\
\text { purpose through } \\
\text { affiliation and sharing. }\end{array}$ & $\begin{array}{l}\text { F- Relativistic: } \\
\text { responding to human } \\
\text { needs, affiliative, } \\
\text { consensual, fluid, } \\
\text { accepting, less efficient }\end{array}$ \\
\hline System-thinking humans & $\begin{array}{l}\text { finding and realizing } \\
\text { self-worth }\end{array}$ & $\begin{array}{l}\mathrm{T} \text { - The world is a chaotic } \\
\text { organism where change } \\
\text { is the norm and } \\
\text { uncertainty is an } \\
\text { acceptable state of } \\
\text { being. }\end{array}$ & $\begin{array}{l}\text { G - Systemic: functional, } \\
\text { integrative, } \\
\text { interdependent, } \\
\text { existential, flexible, } \\
\text { questioning, needs more } \\
\text { time for complexity }\end{array}$ \\
\hline $\begin{array}{l}\text { Holistic communities of } \\
\text { human beings }\end{array}$ & $\begin{array}{c}\text { finding and realizing } \\
\text { self-worth within holistic } \\
\text { system }\end{array}$ & $\begin{array}{c}\mathrm{U}-\mathrm{A} \text { delicately } \\
\text { balanced system of } \\
\text { interlocking forces in } \\
\text { jeopardy at humanities } \\
\text { hands }\end{array}$ & $\begin{array}{c}\text { H - Holistic: experiential: } \\
\text { transpersonal; collective } \\
\text { consciousness; } \\
\text { collaborative; } \\
\text { interconnected }\end{array}$ \\
\hline
\end{tabular}




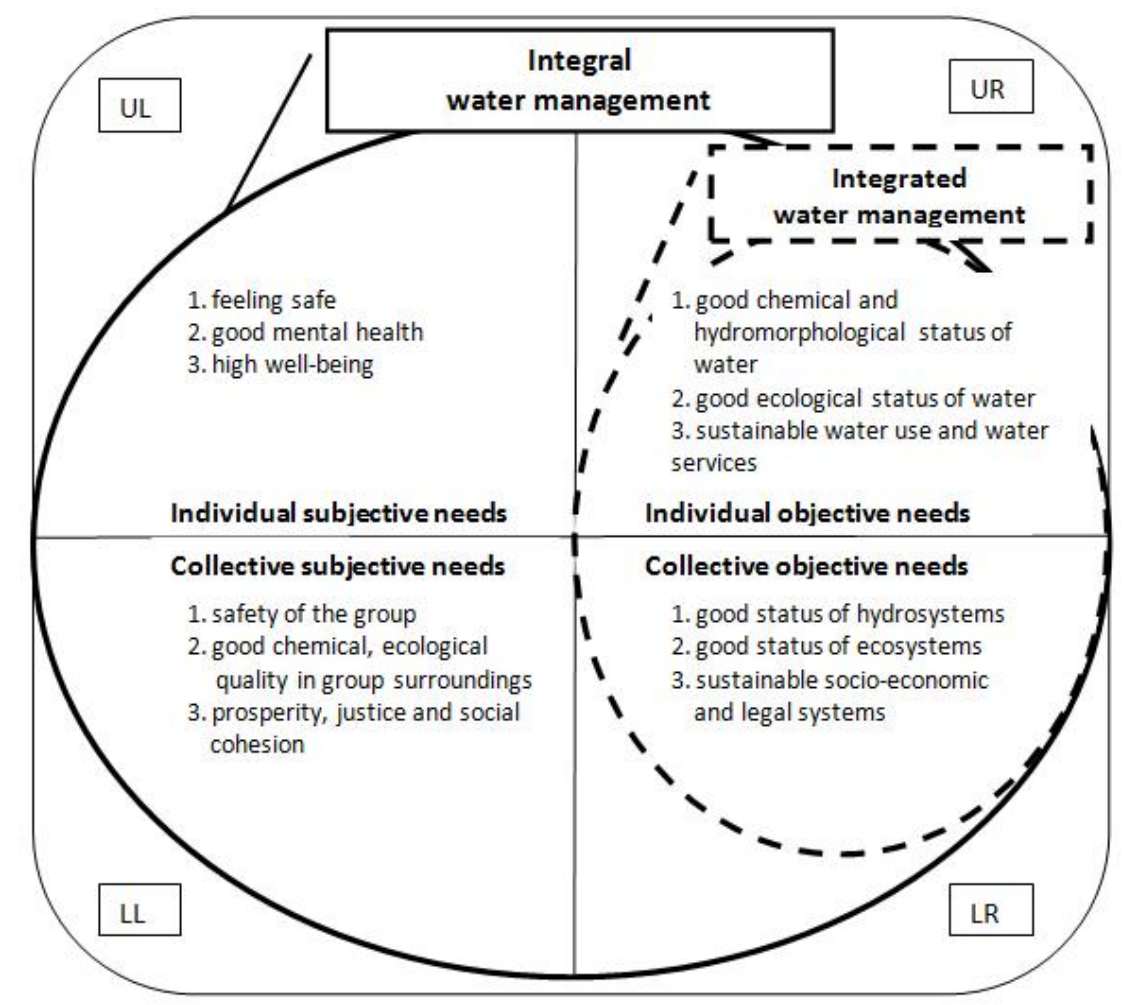

Fig. 1. Integral water management vs. integrated water management

Tab. 2. Systemic, Multiplistic and Absolutistic river management scenarios [10]

\begin{tabular}{|c|c|c|}
\hline Value system & River management & Implementation \\
\hline $\begin{array}{l}\text { E-R Multiplistic } \\
\text { - Conquering the physical uni- } \\
\text { verse } \\
\text { - Oriented at technology and } \\
\text { competition } \\
\text { - Pragmatic }\end{array}$ & $\begin{array}{l}\text { - Cost-benefit analysis } \\
\text { - Dike raising is a cheap option }\end{array}$ & $\begin{array}{l}\text { - Dike raising, groyne lowering } \\
\text { - Removal of hydraulic bottle- } \\
\text { necks } \\
\text { - Removal of vegetation that ob- } \\
\text { structs flow } \\
\text { - Removal of minor embank- } \\
\text { ments } \\
\text { - Retention areas }\end{array}$ \\
\hline
\end{tabular}

\section{F-S Relativistic}

- Living with the human element

- Getting along with others

- Consensual
- Polder mentality, local communities have a say

- Focus on ecology

- Dike raising is no option
- Space for the river combined with ecological restoration

- Cyclic floodplain rejuvenation

- Solutions for individual floodplain sections

- Groyne lowering

\section{G-T Systemic}

- Restoring vision in a disordered world

- Integrative
- Spatially coherent plan for the whole river section

- Participation of local communities

- Water as guiding principle

- Dike raising when needed
- Side channels follow the historic swale channels

- Cyclic floodplain rejuvenation

- Local initiatives in line with the overall direction

- Multi-purpose groyne lowering 
and win-win situations. Conclusions were that (1) analysis of value systems provides a broad interpretive framework for scenario development, which guides the choices for transitions and (2) the biogeomorphology is affected by climate change $(+58 \%$ deposition) but the effects of the local landscaping measures (depending on the dominant value systems) are even stronger [10].

\subsection{Problem Solving with Secondary Water Course Reha- bilitation in Rome Metropolitan Area}

The project "Urban River Basin Enhancement Methods" (URBEM) funded by the European Commission 5th Framework Programme - a study of existing urban river rehabilitation schemes [8] has been carried out. The overall aim of the study was to provide an overview of the state of the art of urban river rehabilitation in Europe, including experiences from countries of other continents. The case studies showed for instance that in most cases the monitoring of river rehabilitation was limited to the measurements of ecological parameters, and although being a vital part of the success of a rehabilitation scheme, ecological aspects alone do not cover all urban aspects. Particularly in urban areas social, aesthetic, and economic aspects must also be considered when dealing with the impact of urban river rehabilitation [8].

One of the URBEMs' case studies was about the Borough of Bella Monaca (subject of the EU urban regeneration program) containing the rehabilitation of the "Bella Monaca Ditch". Goals of the project were to maintain a constant water flow, the treatment of solid waste, the consolidation and enhancement of the morphology and vegetation of the riverbed, to give back an adjacent area to the citizens, and to activate participation and education projects.

The following Table shows how the integral model was used to diagnose water management challenges in the area:

Table 4 shows the objective, inter-objective, subjective and inter-subjective realms of the project. In the objective quadrants soil engineering methods, water quality and quantity, law and regulations, infrastructure, city structure are mapped, while in the subjective quadrants values, individual ethics, traditions, education are shown. It is obvious that low environmental awareness (UL), low respect of laws and regulations, the fact of traditionally abusing water (Egocentric), as well as having little openness for innovation (Absolutistic) can be a basis for limited soil bio engineering methods, (UR) a not comprehensive law and regulation system, competitive administration system and peripherical social problems (LR). A much more complex and resilient water management can be realized, if the links between these processes have been made clear.

\section{Integral water management in Hungary}

\subsection{Value based integral water management in Szigetköz}

Szigetköz is one of Hungary's most precious and most sensitive natural wetlands. However the question of how much society is willing to pay for its protection and rehabilitation is difficult to answer. When rehabilitation becomes necessary, decision makers need to know the economic value of the wetland in order to see society's support for and the financial scale of the investment.

Two methods have been used for the economic evaluation of Szigetköz: benefit transfer and contingent valuation [1]. Benefit transfer evaluates natural resources by transferring available information from studies already completed in another location and/or context. Contingent evaluation method asks individuals how much they are willing to pay (WTP) for the conservation or rehabilitation of a good health status of the wetland.

However the question of ,how much one is willing to pay for Szigetköz" reveals only Szigetköz' ecological state of health. It does not ask for the ,willingness to pay” for avoiding potential problems on human capital and/or for social cohesion caused by the restoration work on Szigetköz. The different versions of restoring the territory may have an enormous effect on local tourism and ecotourism as well as on local people's state of health. As an example several years could be needed for landscaping measures whilst many kilometers of the Danube river bank must not be entered by visitors or locals. Children may grow up without authentically experiencing their own home river bank which can later lead to low environmental awareness and a week sense of place.

Figure 2 shows a possible model of integral planning for Szigetköz rehabilitation. Six alternatives have been developed by different experts with social participation and have been published by the Ministry of Environment. For each of the alternatives the following factors, indicators, and needs are to be considered:

What could further be done is a similar scenario development with the application of the psychosocial development model like it has been done in the case of the Rhine (Table 2). The six different alternatives of the Szigetköz rehabilitation can be interpreted as options for different landscaping measures of different value systems. As the six alternatives have been developed by different representatives of different value systems (NGO's, Ministry, experts, market sector) the dominant value systems directing water management in Hungary could be clarified. This would mean a similar method than applied in the program of the Rome water course rehabilitation where psychosocial levels were identified and linked to water management problems.

In the followings a similar model is presented based on the findings of the project "Common foundation of rehabilitation of branchsystem in Szigetkö-Csallóköz Danube flood area - Social Needs Report" [7]:

Within the quadrant of the collective subjective needs typical conflicts still exists between different interest groups. These conflicts need more attention. The conflicting groups are: the energy and the water sector, lobbyists and decision-makers of the capital and of the country side, experts of different scientific fields, representatives of environmental protection and of water 
Tab. 3. Integral planning for water course rehabilitation in Rome Metropolitan Area [8]

\section{Individual subjective factors}

- Personal responsibility of users and leaders: single persons, private initiative - Relativistic

- Environmental awareness: beginning with new generations

- Personal integrity: abusive system

- Psychosocial level: Absolutistic, Egocentric

- Information and education: beginning

\section{Individual objective factors}

- Water quality: extremely bad

- Quantity: $1000 \mathrm{~mm} / \mathrm{a}$, distribution winter month

- Soil bio engineering methods: limited, presence of sewage collector, solid rock, lack of water, lack of rain, lack of maintenance

- User habits: violence, destruction, little problem awareness

\section{Collective subjective factors}

- Water traditionally: abused

- Respect of laws and regulations: weak

- Environmental awareness: low

- Cultural approach to nature: abusive

- Psychosocial level: Absolutistic, Egocentric in periphery

- Little openness to innovation, participation

- Administrative habits: little problem awareness

- Openness to sustainable use: beginning

\section{Collective objective factors}

- Law and regulations: not comprehensive, not implemented, habit rights

- Polluter pays principle: not applied

- Strategic spatial planning: crisis management

- Urban systems: planning by doing, social problems in periphery, violence

- Provision of basic infrastructure: crisis management

- Administrative system: competition

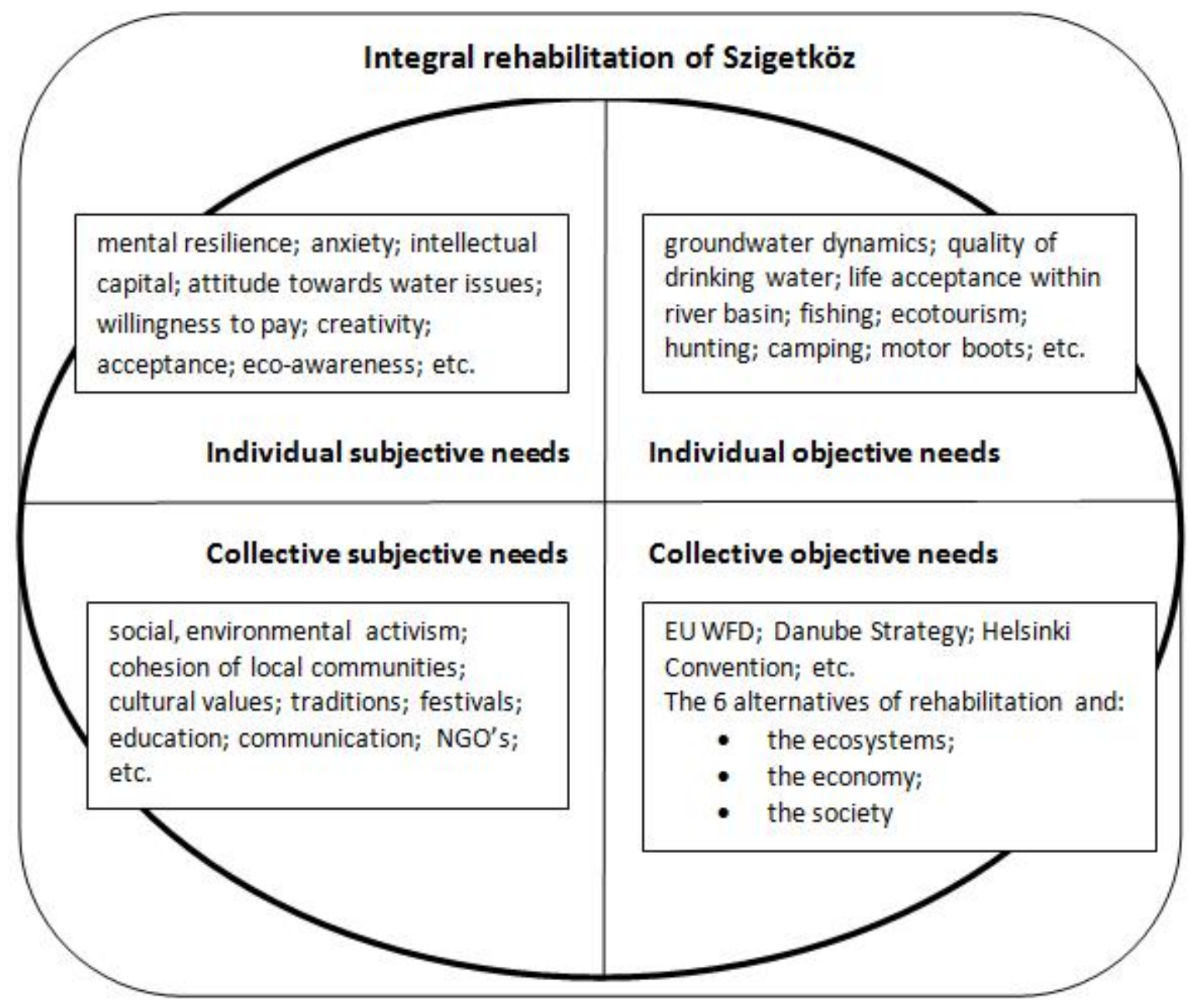

Fig. 2. Integral model of Szigetköz rehabilitation 
Tab. 4. Integral analyses of Szigetköz rehabilitation

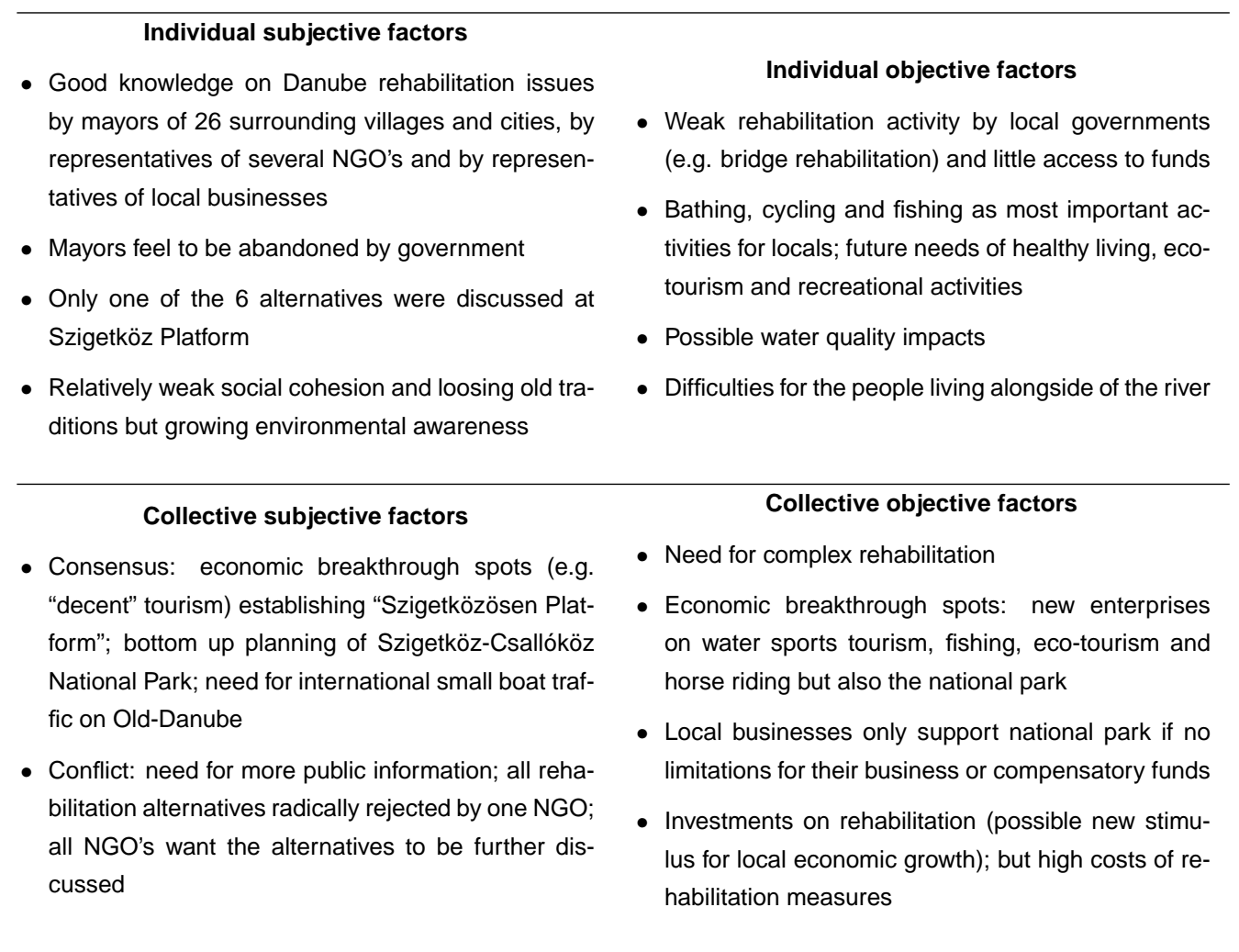

management as well as groups of nature/environment protection.

In order to understand ongoing conflicts according to this issue the alternative landscaping measures could be translated into integral water management scenarios by experts of integrated water management together with experts of psychosocial development. If there is lack of psychosocial development experts, then an introduction of Graves' system may help water engineers, ecologists, economists, modeling experts etc. to clarify the motivations of the different value systems.

\section{Conclusions}

In Hungary forced command economy and absolutistic value system ruled for many decades. Individuality was not dignified, few people took control and lived quite well while talking up "the people". This smaller group was driven by egocentric value system. If a more complex psychosocial value system becomes controlled by a less complex one (Absolutistic controlled by Egocentric) than society gets arrested or moves towards regression instead of moving towards development, innovation and change [11]. In Hungary the Absolutistic value system has been controlled by the Egocentric system. The Egocentric value system has weaker ethical norms and can only understand and solve problems from a less complex neurological point of view. As a few Egocentric elites controlled the forced command economy, neither individual creativity was dignified, nor innovation whilst economic depression, social apathy, growing debts and undergoing regulations as accepted social norm appeared.
These symptoms seem to be still alive, so we may consider that Hungary has been arrested in the conflict between the Egocentric and Absolutistic value system. Before Hungary can stabilize at a healthy "democratic" Multiplistic level - problems of the Egocentric level must be solved. According to Graves [5] for that purpose first a healthy conservative structure of the Absolutistic psychosocial level must stabilize as inevitable criteria for the next level. If Multiplistic level is healthy within the society than intellectual property, creativity, and innovation rule. In this situation water management negotiations can result in real win-win solutions. (However Relativistic and Systemic levels with their needs for functional sustainability and social harmony - are still quite far away on the horizon.)

All of these "hidden" processes belong to the subjective and inter-subjective quadrants of the integral water management model. Without having information about these hidden interior processes - decision making will only be based on half of the truth. If interior reality lacks on consensus than objective quadrants alone can not offer win-win solutions.

\section{Acknowledgment}

The work reported in the paper has been developed in the framework of the project ,Talent care and cultivation in the scientific workshops of BME" project. This project is supported by the grant TÁMOP-4.2.2.B-10/1-2010-0009. 


\section{References}

1 Bartus G, A Szigetköz természeti kincseinek közgazdasági értéke. In: Alexay Z. et al: Az eddig a legközelebb álló szlovák és magyar javaslatok ökológiai hatásainak vizsgálata és a közös összekapcsolt ágrendszer ökológiai peremfeltételeinek meghatározása, Magyar Környezetgazdaságtani Központ; Budapest, 2007. Kutatási zárótanulmány.

2 Csete M, Für A, Modeling methodologies of synergic effects related to climate change and sustainable energy management, Periodica Polytechnica Social and Management Sciences, 18(1), (2010), 11-19, DOI 10.3311/pp.so.2010-1.02

3 Esbjörn-Hargens S, Integral Ecology: The what, who, and how of environmental phenomena, World Futures, 61, (2005), 5-49, DOI 10.1080/02604020590902344

4 Für A ljjas, Climate Change: Innovative Approaches for Modeling and Simulation of Water Resources and Socioeconomic Dynamics, In: Chetri N (ed.), Human and Social Dimensions of Climate Change, InTech Open Access Publisher, 2012, pp. 1-22, DOI 10.5772/3242 ISBN: 978-953-51-0847-4.

5 Graves CW, Human Nature Prepares for a Momentous Leap, The Futurist, 4, (1974), 72-87.

6 Paulson DS, Wilber's Integral Philosophy: A Summary and Critique, Journal of Humanistic Psychology, 48(3), (2008), 364-388, DOI 10.1177/0022167807309748

7 Pisztráng Kör Egyesület, A Szigetköz-Csallóközi Duna ártér mellékágrendszere rehabilitációjának közös megalapozása, Társadalmi igényelemzés végleges tanulmány, Mosonmagyaróvár Környezetvédelméért Közalapítvány, 2007, http://www.szigetkozosen.hu/index.php?p= list@docs\&cid=3 Magyarország - Szlovákia - Ukrajna Szomszédsági Program, az Európai Unió és a Magyar Köztársaság társfinanszírozásával.

8 Schanze J Olfert, Urban River Basin Enhancement Methods, Leibniz Institute of Ecological and Regional Development, Dresden University of Technology, 2004. funded by European Commission 5th Framework Programme, Key Action 4. "City of tomorrow and cultural heritage" Existing Urban River Rehabilitation Schemes, Work package 2, Final Report.

9 Shelley SI, Directional hypotheses for models of helping and coping using Graves's theory, American Psychologist, 38(4), (1983), 501-502, DOI 10.1037/0003-066X.38.4.501

10 Straatsma M, Schipper A, van der Perk M, van den Brink C, Leuven $\mathbf{R}$, Middelkoop $\mathbf{H}$, Impact of value-driven scenarios on the geomorphology and ecology of lower Rhine floodplains under a changing climate, Landscape and Urban Planning, 92, (2009), 160-174, DOI 10.1016/j.landurbplan.2009.04.004

11 Van Marrewijk M, Strategic Orientations: Multiple Ways for Implementing Sustainable Performance, Technology and Investment, 1, (2010), 85-96, DOI 10.4236/ti.2010.12010 